\title{
Safety culture regarding zoonoses on domestic
} ruminant farms

\author{
J. Starič* J. J. Hodnik, K. Drusany Starič, J. Ježek, N. Janev Holcer, \\ J. Leppälä and R. Rautiainen
}

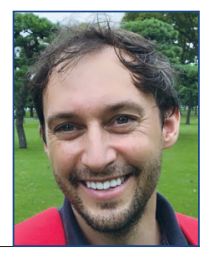

\begin{abstract}
Veterinarians in buiatric practice, alongside veterinary care and animal welfare, are also responsible for protecting assisting personnel and those working on the holding from zoonoses. Therefore, they need to be knowledgeable about common zoonotic diseases of ruminants, in particular, and protection from their contraction. Veterinarians should know which zoonotic diseases are present in their country and neighbouring countries to be prepared to advise. Zoonotic diseases of ruminants often show no typical clinical presentation, so awareness of self-protective behaviour when dealing with animals in the prevention
\end{abstract}

of zoonoses is very important. This article provides a review of the common zoonoses of domestic ruminants in South-East Europe that are transmitted when handling animals, and their manner of transmission to humans. Safety culture in ruminant production relates to employee attitudes and behaviour concerning health and safety, which also has a significant impact on zoonosis prevention. Improving the safety culture among livestock sector workers and worker behaviours that prevent the risk of zoonoses are also discussed.

Key words: pathogen; occupational health; worker; infectious diseases; animals

\section{Introduction}

Zoonoses are infections that spread naturally between species of animals to humans and vice versa. According to the WHO, over 200 zoonoses have been identified worldwide, with 45 known bovine zoonoses (McDaniel et al., 2014).

Zoonoses are often occupational diseases that principally affect animal breeders, veterinarians and/or slaughterhouse workers (Collins and Wall, 2004; Ganter, 2015). The probability of their spread is determined by the interactions of several

Jože STARIČ* ${ }^{*}$ DVM, MSc, PhD, Spec. Buiatrics, Associate Professor, (Corresponding author, e-mail: joze.staric@vf.uni-lj.si), Jaka Jakob HODNIK, DVM, assistant, Jožica JEŽEK, DVM, PhD, Spec. Buiatrics, Assistant Professor, Veterinary Faculty, University of Ljubljana, Ljubljana, Slovenia; Kristina DRUSANY STARIČ, MD, PhD, Spec. obstetrics and gynaecology, Assistant, Division of Gynaecology and Obstetrics, University Clinical Centre Ljubljana, Slovenia; Nataša JANEV HOLCER, BEng., PhD, Assistant Professor, Croatian Institute of Public Health, Zagreb, Croatia and Faculty of Medicine Rijeka, Rijeka, Croatia; Jarkko LEPPÄLÄ, DSc(Tech), MSc, Research Scientist, Natural Resources Institute Finland (Luke), Risto RAUTIAINEN, PhD, MSc, Full Professor, University of Nebraska Medical Center, Omaha, Nebraska, USA 
factors, including disease dynamics in the reservoir host, pathogen exposure and within-human factors, especially susceptibility to infections (Plowright et al., 2017). They can spread through direct contact with animals, indirect contact by fomites and environment, oral transmission, most commonly with food or water, aerosol transmission and with vectors (Trevino, 2006; Ganter, 2015). Often, they do not show typical clinical presentation in either animals or humans. In humans, zoonotic symptoms are often similar to those of more common illnesses, like flu, and therefore they are generally misdiagnosed and underreported. Ruminants are often asymptomatically infected, but still shed the pathogen. Veterinarians should know which zoonotic diseases are present in their country and the neighbouring countries in order to advise persons dealing with animals how to protect themselves in general, and especially in the case of an outbreak. Zoonotic diseases are expanding globally, due to a range of factors, including climate change that has brought new diseases and vectors to our doorstep, animal movements between farms, countries and continents, intensive animal production with high stocking density, global distribution of animal feed, and demographic change, including migrations. This review article is aimed at providing information on zoonotic diseases of domestic ruminants, focusing in particular on South East Europe. The focus is on people in professions or jobs with direct contact to domestic ruminants (e.g., farmers and their families, butchers, abattoir workers, veterinarians, veterinary technicians, laboratory personnel) who are at high risk of acquiring zoonoses (Sanchez et al., 2018). The European Centre for Disease Prevention and Control database was consulted for identification of domestic ruminant zoonoses present in South East European countries, which are reported pursuant to the Zoonoses Directive (2003/99/EC), and the literature was also consulted. Approaches for protecting farm workers from infection with zoonosis are also discussed.

\section{Zoonosis hazards relevant for working with domestic ruminants}

The identified zoonoses that can be transmitted to humans through direct or indirect contact with live domestic ruminants in Central Europe are cryptosporidiosis, giardiasis, infections with parapox viruses, rabies, noroviruses, leptospirosis, tuberculosis, listeriosis, brucellosis, Q fever, chlamydiosis, salmonellosis, campylobacteriosis, dermatophilosis, colibacillosis, clostridiosis, anthrax, staphylococcal infections and dermatophytosis. Analysis of the more prevalent zoonoses of domestic ruminants, the modes of transmission, and their clinical presentations are presented below.

\section{Cryptosporidiosis}

Cryptosporidiosis is a protozoal parasitic disease caused by Cryptosporidium parvum that multiplies rapidly and inhabits the intestine of cattle. It is also capable of auto-infection of the host, making it a very successful parasite. Neonatal calf diarrhoea is a common consequence of infection in calves up to 3 weeks. Many calves are also asymptomatic carriers of Cryptosporidium parvum (Thomson et al., 2017). Humans can become infected by ingestion or inhalation (very rarely) of Cryptosporidium parvum oocysts, which are shed in large quantities in faeces by infected calves, including asymptomatic ones. Oocysts are very resistant in the environment and contaminate the environment and the pelage of calves. Symptoms in infected humans include profuse, watery diarrhoea, which can 
be associated also with fever, vomiting, cramping, abdominal pain and rash. The disease is self-limiting and usually does not require special treatment. However, in immunocompromised persons, the disease can be severe and life-threatening, requiring hospitalisation and intensive treatment (Alsmark et al., 2018). There are literature reports about the transmission of the disease to veterinary students attending to calves with diarrhoea (Thomson et al., 2017). General preventive measures apply for cryptosporidiosis prevention (see section Preventive measures against zoonoses).

\section{Parapoxviruses of domestic ruminants}

Infections with viruses from the genus Parapoxvirus are common and cosmopolitan in domestic ruminants, and are also highly prevalent in South East Europe. In small ruminants, the Orf virus causes contagious ecthyma, while in cattle, the Bovine papular stomatitis virus and Pseudocowpox virus cause papular stomatitis and pseudocowpox, respectively (McDaniel et al., 2014; Ganter, 2015). Clinical presentation of contagious ecthyma includes papillomatous lesions that are typically eroded on the lips, mouth, nare most commonly, but often also on teats and pudendum. Papular stomatitis typically presents with papules that become eroded on the planum nasolabiale, lips and mouth of young cattle, the same can be true for pseudocowpox where additionally umbilicated papules can be found on the udder and teat skin of adult cows. The diseases are transmitted through direct contact with the skin of infected animals or with fomites. All three diseases cause similar umbilicated papules with an erythematous halo, usually on the hands of infected humans. The disease in humans is self-limiting, and lesions usually disappear within 3 weeks (Trevino, 2006). General preventive measures apply for the prevention of parapoxviruses infections (see section Preventive measures against zoonoses).

\section{Brucellosis}

Infections with the bacteria Brucella melitensis and Brucella abortus induce abortion in the second half of pregnancy, or result in premature births, week offspring, retained placenta and infertility in domestic ruminants. Animals are mainly infected by ingestion or inhalation of the bacteria, which are then shed with placenta, uterine fluids, and urine. Once infected, most animals will shed the organisms in milk for life. Humans can be infected when their conjunctival or oronasal mucosa, or abraded skin is exposed to the excretions of infected animals. The highest bacterial shedding is around parturition. They may also become infected by ingestion of contaminated animal products, mainly dairy products (Collins and Wall, 2004; Ganter, 2015). Skin, wool, manure and maintenance equipment of farm premises are also a source of infection. The global estimate in humans is 500,000 new cases per year (Pappas et al., 2006), which is likely underestimated and underreported given the difficulties in diagnosis of this disease, which although grave, lacks pathognomonic symptoms. The disease in humans, also called Malta fever, can be insidious and may be present in many atypical forms. The most common signs include undulant fever, fatigue, headaches, sweats, arthralgia, chills, malaise, weight loss and myalgia. Spontaneous abortions, mainly in the first or second trimester of pregnancy, have been seen in women. Inadequate treatment is responsible for severe and debilitating long-standing disease, with severe complications such as endocarditis or neurobrucellosis, but the overall fatality rate is less than $1 \%$. Prevention of human brucellosis is based on control of the disease in animals and on education of people directly involved in the animal 
and food industries (Rodolakis, 2014, Ganter, 2015).

\section{Chlamydia infection}

Chlamydia abortus (formerly Chlamydophila abortus and Chlamydia psittaci) is one of the most common causes of abortions and reproductive disorders in small ruminants. Abortion occurs in primipara or naïve animals in late pregnancy with no previous, specific clinical signs, although occasionally bloody vaginal discharge can be observed a few days before abortion. The placenta is necrotic, with lesions affecting both cotyledons and intercotyledonary spaces, which are often thickened, necrotic and haemorrhagic at the edges of the lesions. Foetuses may be aborted necrotic, well preserved, or, rarely, mummified. Weak and stillborn lambs and kids are also common. Infected males may present with epididymitis (Menzies, 2011). Transmission of C. abortus from small ruminants to humans occurs through inhalation of infectious dust and aerosols during or after abortion or normal parturition. In humans, the organism induces asymptomatic infection or mild flu-like illness, headache, conjunctivitis, urogenital infections or, in rare cases, pneumonia. In pregnant women, the infection can lead to abortion with a series of complications (Meijer et al., 2004; Rodolakis, 2014). Prevention depends on its control in animals, training of farmers and the exposed population in general. Control of the disease in small ruminants is based on strict biosecurity and sanitation measures, strategic administration of antibiotics and vaccination of susceptible animals with attenuated or inactivated vaccines (Ganter, 2015).

\section{$Q$ fever}

$Q$ fever is caused by the bacterial species Coxiella burnetii. In small ruminants and cattle, the infection is generally subclinical though it has a strong tendency to persist in the uterus and mammary gland. Large disease outbreaks are possible and are characterised by abortion, stillbirth or delivery of weak newborns, as well as placentitis or post-partum metritis when naïve animals are infected during pregnancy (Angelakis and Raoult, 2010). The main routes of human infection are inhalation of infective dust/aerosols, especially from ruminants, and direct contact with infected animals. Infection with ingestion of contaminated milk is also possible. C. burnetii has a very low infective dose. Humans are asymptomatic in most cases. However, in acute cases patients, show flu-like symptoms with fever up to $40{ }^{\circ} \mathrm{C}$, shivering, headache, fatigue, muscular pain, anorexia and coughing. In rare cases, hepatitis, myocarditis, peri- or endocarditis and neurological manifestations may be seen. The main preventive measures consist of controlling the disease in the animal population (biosecurity, vaccination, culling) and vaccination of high-risk population of humans (persons with cardiovascular conditions) and the use of personal protective equipment when working with infected animals (Rodolakis, 2014; Ganter, 2015).

In March 2007, a group of 33 high school veterinary students and two teachers contracted a $Q$ fever infection during a training course on a sheep farm in Slovenia. As part of their training, 45 students spent several hours a day on a sheep farm from $5^{\text {th }}$ to $23^{\text {rd }}$ March 2007, together with three teachers. They were trimming sheep's hooves, disinfecting wounds, injecting intramuscular vitamins $\left(\mathrm{AD}_{3} \mathrm{E}\right)$ and anti-helminthic injections to healthy animals as per disease prevention protocol at the farm with approximately 500 sheep. The lambing season on the farm was from the end of January till mid-March that year, with an acceptable abortion rate (recorded less than $2 \%$ ) and no clinical indications of $Q$ fever (Grilc et al., 2007). 


\section{Leptospirosis}

Leptospirosis is a disease caused by fragile, motile, spiral-shaped bacteria. Cattle are maintenance hosts of L. borgpetersenii serovar Hardjo and L. interrogans serovar Hardjo. Serovars of L. interrogans that can infect humans as well as ruminants are also Icterohaemorrhagiae, Grippotyphosa and Tarassovi. Rodents are a reservoir of these and many other serovars (Trevino, 2006). In adult animals, the most prominent signs of infection are abortions, decreased fertility or decreased milk yield and other reproductive disorders, especially in serovars for which cattle are the maintenance hosts. Jaundice and haemoglobinuria may be seen in severely affected animals. In calves, symptoms include fever, anorexia, conjunctivitis and diarrhoea. In small ruminants, the disease is less severe than in cattle. Leptospirosis is usually spread with urine or afterbirth of infected animals. Humans can contract leptospirosis by ingesting contaminated food or water, inhaling aerosolized urine or water, or through direct contact with the softened skin and mucous membranes. The incubation period is from 2 to 30 days (McDaniel et al., 2014). In humans, the disease may range from mild to severe. Symptoms include flulike illness, weakness, vomiting, mental confusion, jaundice and neck stiffness. Severe cases can lead to damage of the liver, kidney or central nervous system. Mortality can reach up to $10 \%$. Control measures include control of the rodent population, use of personal protective equipment and vaccination of animals (Trevino, 2006; Ganter, 2015).

\section{Listeriosis}

Listeriosis is caused by the bacterium Listeria monocytogenes. This bacterium is widespread in theenvironment, especially in soil (geophilic bacterium). Animals usually contract the disease by eating contaminated silage. Listeria can cause encephalitis, silage eye, abortion, sepsis and mastitis. The signs of illness due to encephalitis are facial paralysis, drooling of saliva, lack of coordination, falling, circling to one side and head pressing. Abortions and stillbirths mainly occur late in gestation. The infection can also be localized causing mastitis or uveitis. Most infections with listeriosis in humans are caused by ingesting the bacteria in food, though inhalation is also possible, although not as common. Contaminated food sources usually include raw meat and unpasteurized dairy products. The incubation period is 3 to 70 days. Listeriosis is a more serious problem in pregnant women, new-borns, the elderly and people with a weak immune system. Women can become infected during pregnancy and usually show no signs of illness themselves, though the disease can cause death of the foetus during the second half of pregnancy. Listeriosis in new-borns, elderly or those with a weak immune system can manifest as sepsis, meningitis or meningoencephalitis (Trevino, 2006; Ganter, 2015). There are reports of local cutaneous skin infections with Listeria monocytogenes in veterinary practitioners and farm workers who developed pustular changes on the skin of arms and hands after assisting with the delivery of a stillborn calf or working with sick animals (Zelenik et al., 2014). Prevention measures are based on the personnel education and hygiene in food preparation (Trevino, 2006; Ganter, 2015).

\section{Tuberculosis}

Tuberculosis is caused by bacteria from the Mycobacterium tuberculosis complex. Early stages of the infection often show no clinical signs. As the disease progresses, weight loss, anorexia, weakness, and a low-grade fever are common. If the disease involves the lungs, animals will have a cough and may have dyspnoea. Other 
signs may include lymphadenitis and mastitis. Tuberculosis can infect humans and the most common route of infection is from ingesting raw (unpasteurized) milk or eating dairy products made from raw milk (Cvetnić et al., 2007). Less commonly, the bacteria can enter the body by inhalation or via wounds in the skin. A person can be infected with tuberculosis without showing any signs of illness. It can infect the lungs (pulmonary tuberculosis) causing fever, chest pain and the person may cough up blood. The disease can also spread throughout the body affecting kidneys, spine and brain. Control of spread to humans is achieved through education of workers, food hygiene and the control of the disease in the animal population (Trevino, 2006; Ganter, 2015).

\section{Dermatophytosis}

Dermatophytosis (Ringworm) is a fungal infection caused by the species of the genera Trichophyton and Microsporum. Animals usually become infected through direct contact or with fomites. Typically, areas of hair loss are seen, with skin scaling and crusting. Skin lesions are typically concentric, "ringworm" lesions and may or may not be itchy. Humans become infected in the same way as animals. Infected people can also spread ringworm to other people and animals. The disease is one of the most common zoonosis in farm workers (Sanchez et al., 2018). Symptoms of ringworm usually occur 1 to 4 weeks after infection (McDaniel et al., 2014). In humans the disease is called tinea. The most common symptom is itchiness and lesions that are most inflamed at the edges, with redness, scaling, and occasional blistering. The best prevention measures are vaccination of animals for Trichophyton verrucosum, use of personal protective equipment when handling animals (gloves, caps, coveralls) and good personal hygiene (Trevino, 2006; Ganter, 2015).

\section{Preventive measures against}

\section{zoonoses}

The risk of zoonosis cannot be eliminated on a farm, though it can be significantly reduced. Although many zoonotic pathogens are easily killed outside their hosts, it is important that infection prevention measures are followed when handling infected or potentially infected animals, as many zoonotic diseases are often subclinical in animals. That is why awareness of the various routes of transmission becomes so essential when developing a strategy to minimize the risk of zoonotic diseases. For nearly all diseases, there is a relationship between infectious dose and severity of the disease. A threshold dose is required to establish infection, and low doses may cause only mild infections, which can also be asymptomatic. Developing risk control tools for better safety culture and risk management on farms is important. There are many general prevention steps that could be implemented to prevent zoonotic disease. Safety culture in dealing with animals as a potential risk for zoonosis transmission means that workers are aware of the risk, promote and discuss safe behaviour, and practice it in their daily work. This has a major effect on prevention of zoonoses (Robin et al., 2017). Good education of stockmen and farmers is necessary for successful control of zoonoses, as workers need to know why certain measures are important and how they are applied in order to comply with implemented protocols. Promoting personal hygiene especially to prevent faecal-oral transmission (major route for enteric pathogen transmission, as in salmonellosis, colibacillosis, campylobacteriosis, cryptosporidiosis etc.), by washing hands after handling animals, not consuming food or drink in animal facilities and wearing personal protective equipment such as gloves, caps and coveralls, should be a routine practice. 
By washing hands and showering after handling animals, the risk of exposure decreases as the infectious agents have been removed. Additionally, the use of personal protective equipment can reduce a person's exposure to zoonotic diseases. Wearing gloves is especially important if one has cuts or abrasions on their hands when exposed, as this may enable pathogens easier infection. Coveralls will help keep clothes clean and cover arms to minimize disease exposure when handling animals. Contaminated clothes are also a mean of transmission of zoonotic diseases to family members, so it is important that clothes used on the farm are not worn at home. Finally, when working with known infectious animals, and there is a risk of airborne spread while handling or treating an animal or when performing a necropsy, wearing a respirator mask and goggles can decrease exposure (Trevino, 2006). In order to follow these recommendations, it is necessary that each holding keeping domestic ruminants has facilities that can enable good practices, including changing rooms, toilets, washing facilities and facilities where workers can rest and eat during a break. To reduce zoonoses on a farm, the zoonosis risk has to be identified, control measures implemented, and risk monitored. A strict biosecurity plan, including vector and vermin control programme and good husbandry practices (such as segregating age cohorts, colostrum feeding, sanitation, and segregation of sick animals) with systematic surveillance should be implemented (Collins and Wall, 2004). Healthy animals are the best prevention of zoonoses.

\section{Conclusions}

Zoonotic diseases are a major threat to human health, especially in specific occupations, including persons who work with live ruminants. Most zoonosis risks can be effectively reduced through simple precaution measures, such as adequate hygiene (e.g. washing and disinfection of hands) and the use of appropriate personal protective equipment. More contagious zoonoses require more personal protective equipment and other control measures, like the eradication of the disease in the animal population, or in the case of vector borne diseases, control of the vector population. When it comes to foodborne pathogens, care must be taken to thoroughly cook or pasteurise food before consumption and to separate prepared food from raw food. Veterinarians are responsible for informing and educating stakeholders and the public of the risks associated with working with animals and consuming animal products, and demonstrating best infection prevention practices while working.

Those particularly vulnerable to contracting zoonosis are persons on immunosuppressive medication, those with immunosuppressive diseases, children, the elderly and pregnant women. Persons belonging to these vulnerable groups should avoid contact with domestic ruminants or strictly follow zoonosis prevention guidelines.

\section{Acknowledgment}

This contribution is a result of cooperation within the COST Action CA16123 Safety culture and risk management in agriculture (SACURIMA).

\section{References}

1. ALSMARK, C., P. NOLSKOG, A. L. ANGERVALL et al. (2018): Two outbreaks of cryptosporidiosis associated with cattle spring pasture events. Vet. Parasitol.: Regional Studies and Reports 14, 71-74.

2. ANGELAKIS, E. and D. RAOULT (2010): Q Fever. Vet. Microbiol. 140, 297-309.

3. COLLINS, J. D. and P. G. WALL (2004): Food safety and animal production systems: controlling zoonoses at farm level. Rev. Sci. Tech. 23, 685-700.

4. CVETNIC, Z., V. KATALINIC-JANKOVIC, B. SOSTARIC et al. (2007): Mycobacterium caprae in 
cattle and humans in Croatia. Int. J. Tuberc. Lung. Dis. $11,652-658$.

5. GANTER, M. (2015): Zoonotic risks from small ruminants. Vet. Microbiol. 181, 53-65.

6. GRILC, E., M. SOČAN, N. KOREN et al. (2007): Outbreak of $\mathrm{Q}$ fever among a group of high school students in Slovenia, March-April 2007. Eurosurveillance 12 (29).

7. McDANIEL, C. J., D. M. CARDWELL, R. B. MOELLER Jr and G. C. GRAY (2014): Humans and cattle: a review of bovine zoonoses. Vector Borne Zoonotic Dis. 14, 1-19.

8. MEIJER, A., A. BRANDENBURG, J. de VRIES et al. (2004): Chlamydophila abortus infection in a pregnant woman associated with indirect contact with infected goats. Eur. J. Clin. Microbiol. Infect. Dis. 23, 487-490.

9. MENZIES, P. I. (2011): Control of important causes of infectious abortion in sheep and goats. Vet. Clin. North. Am. Food. Anim. Pract. 27, 81-93.

10. PAPPAS, G., P. PAPADIMITRIOU, N. AKRITIDIS et al. (2006): The new global map of human brucellosis. Lancet Infect. Dis. 6, 91-99.

11. PLOWRIGHT, R. K., C. R. PARRISH, H. McCALLUM et al. (2017): Pathways to zoonotic spillover. Nat. Rev. Microbiol. 15, 502-510.
12. ROBIN, C., J. BETTRIDGE and F. McMASTER (2017): Zoonotic disease risk perceptions in the British veterinary profession. Prev. Vet. Med. 136, 39-48.

13. RODOLAKIS, A. (2014): Zoonoses in goats: How to control them. Small Rum. Res. 121, 12-20.

14. THOMSON, S., C. A. HAMILTON, J. C. HOPE, F. KATZER, N. A. MABBOTT, L. J. MORRISON and E. A. INNES (2017): Bovine cryptosporidiosis: impact, host-parasite interaction and control strategies. Vet. Res. $48,42$.

15. SÁNCHEZ, A., M. PRATS-van der HAM, J. TATAY-DUALDE, A. GARCÍA-GALÁN, C. de la FE, J. C. CORRALES and A. CONTRERAS (2018): Zoonoses and occupational health in the veterinary profession. Rev. Esp. Salud Publica 92, e201812086.

16. TREVINO, I. (2006): Practical Applications for Managing Biological Risks Zoonotic Transmission Control for Dairy Producers. Ames: Centre for Food Security and Public Health Iowa State University.

17. ZELENIK, K., J. AVBERŠEK, M. PATE, M. LUŠICKY, B. KRT, M. OCEPEK and I. ZDOVC (2014): Cutaneous listeriosis in a veterinarian with the evidence of zoonotic transmission-a case report. Zoonoses Public Health. 61, 238-241.

\section{Biosigurnost od zoonoza na farmama za uzgoj domaćih preživača}

Dr. sc. Jože STARIČ, dr. med. vet., specijalist iz bujatrike, izvanredni profesor, Jakob HODNIK, dr. med. vet., asistent, dr. sc. Jožica JEŽEK, dr. med. vet., specijalistica iz bujatrike, izvanredna profesorica, Veterinarski fakultet Univerziteta u Ljubljani, Ljubljana, Slovenija; dr. sc. Kristina DRUSANY STARIČ, dr. med., Specijalistica ginekologioje i porodiljstva, asistentica, Odjel za ginekologiju i porodiljstvo, Univerzitetski klinički centar Ljubljana, Ljubljana, Slovenija; dr. sc. Nataša JANEV HOLCER, dipl. ing., docentica, Hrvatski zavod za javno zdravstvo, Zagreb, Hrvatska i Medicinski fakultet u Rijeci, Rijeka, Hrvatska; dr. sc. Jarkko LEPPÄLÄ, magistar poljoprivrede i šumarstva, znanstveni istraživač, Institut za prirodne resurse Finske (Luke), Helsinki, Finska, dr. sc. Risto RAUTIAINEN, magistar poljoprivrede, redoviti profesor, Univerzitet u Nebraski Medicinski centar, Omaha, Nebraska, SAD

Veterinari su u buiatričkoj praksi, uz veterinarsku skrb i dobrobit životinja, odgovorni i za zaštitu pomoćnog osoblja i osoblja koje radi na gospodarstvima od zoonoza. Stoga trebaju posjedovati znanje o uobičajenim zoonotskim bolestima preživača, posebno o zaštiti od obolijevanja od takvih bolesti. Veterinari bi trebali znati koje su zoonotske bolesti prisutne u njihovoj, kao i u susjednim zemljama kako bi bili spremni savjetovati osoblje na gospodarstvima. Zoonotske bolesti preživača često ne pokazuju nikakve tipične kliničke znakove, stoga je svijest o ponašanju u svrhu samozaštite kada se radi sa životinjama vrlo bitna u prevenciji zoonoza. Ovaj članak sa- drži analizu uobičajenih zoonoza u domaćih preživača u jugoistočnoj Europi koje se prenose radeći sa životinjama te načina njihovog prenošenja na ljude. Osviještenost djelatnika o sigurnosti zaštite od zoonoza u proizvodnji preživača odnosi se na stavove i ponašanje zaposlenika u svezi zdravlja i sigurnosti, što isto tako ima znatan učinak na prevenciju zoonoze. Ujedno se raspravlja o povećanju osviještenosti djelatnika o sigurnosti zaštite od zoonoza među djelatnicima u stočarskom sektoru i ponašanjima radnika koja sprječavaju rizike od zoonoza.

Ključne riječi: patogen; zaštita zdravlja na radu; djelatnik; zarazne bolesti; životinje 